HELICOBACTER PYLORI

\title{
Effect of physiological concentrations of vitamin $C$ on gastric cancer cells and Helicobacter pylori
}

\section{Z-W Zhang, M Abdullahi, M J G Farthing}

See end of article for authors' affiliations

\section{Correspondence to} Dr Z W Zhang, Level 7, Bristol Royal Infirmary, University of Bristol, Bristol BS2 8HW, UK;

z.w.zhang@bristol.ac.uk

Accepted for publication 3 May 2001

\begin{abstract}
Background: Gastric juice vitamin C may be protective against gastric carcinogenesis but concentrations are significantly reduced by Helicobacter pylori infection. We investigated the in vitro effects of vitamin $\mathrm{C}$ at concentrations comparable with those found in gastric juice on gastric cancer cells and $H$ pylori.

Methods: Gastric cancer cell lines and various $H$ pylori strains were treated with L-ascorbic acid for up to 72 hours. Cell viability, and protein and DNA synthesis were determined. Flow cytometry was used for assessment of $H$ pylori adherence, cell cycle distribution, and apoptosis. $H$ pylori growth and its haemagglutination activity were determined using viability count and microtitration assay.

Results: Vitamin C induced a significant dose dependent growth inhibition of gastric AGS and MKN45 cells but this effect was significantly reduced at levels similar to those in gastric juice of $\mathrm{H}$ pylori infected patients $(<50 \mu \mathrm{M})$. Although vitamin $\mathrm{C}$ had no obvious effect on $\mathrm{H}$ pylori growth, haemagglutination activity, or adherence ability to gastric AGS cells compared with untreated controls, it significantly enhanced $H$ pylori associated apoptosis and induced cell cycle arrest in these cells.

Conclusion: Vitamin $\mathrm{C}$ may inhibit gastric cancer cell growth and alter $\mathrm{H}$ pylori induced cell cycle events at concentrations comparable with those in gastric juice, but has no effect on $\mathrm{H}$ pylori growth or pathogenicity. However, the inhibitory effect on gastric cancer cells was lost at vitamin C concentrations found in patients with $\mathrm{H}$ pylori infection.
\end{abstract}

$\mathrm{C}$ hronic infection of Helicobacter pylori has been linked to the development of gastric adenocarcinoma. ${ }^{1}$ Although astric juice vitamin $\mathrm{C}$ has recently attracted many researchers. ${ }^{2}$ This is not only because of the inter-relationship between vitamin $\mathrm{C}$ and $\mathrm{H}$ pylori in the stomach but also because growing evidence suggests that dietary vitamin $\mathrm{C}$ reduces gastric cancer risk. ${ }^{3}$ It has been shown that vitamin $\mathrm{C}$ reduces the formation of $N$-nitroso compounds (NOCs) in gastric juice and scavenges reactive oxygen metabolites (ROMs) in gastric mucosa. ${ }^{4}$ Reduced levels of vitamin $\mathrm{C}$ in gastric juice have been reported in $H$ pylori infected patients, which return to normal after eradication of the organism. ${ }^{35}$ It is thought that decreased concentrations of gastric juice vitamin C diminish its protective effect and therefore increase the risk of gastric cancer. However, evidence from epidemiological and case control studies is mainly based on vitamin C concentrations in serum or plasma ${ }^{2}$ but there are no direct data relating low gastric juice vitamin $\mathrm{C}$ levels to the increased gastric cancer risk. Furthermore, most previous studies suggest that $H$ pylori infection does not influence vitamin C concentrations in serum or plasma. ${ }^{46}$

Vitamin $\mathrm{C}$ is an acidic molecule with strong reducing activity and is an essential component of most living tissues. It has two major forms: ascorbic acid and dehydroascobic acid (DHA) which all have vitamin $\mathrm{C}$ activity and are interconvertible by redox chemistry. ${ }^{7}$ It has been shown that both ascorbic acid and DHA can affect cell growth by altering cell proliferation and/or inducing cell death in various cell systems. ${ }^{8}$ 9 Ascorbic acid induced growth inhibition in various human melanoma cells ${ }^{10}$ and apoptotic cell death in human promyelocytic leukaemic HL-60 cells ${ }^{11}$ and in fibroblasts. ${ }^{12}{ }^{13}$ The effects were significantly enhanced in the presence of a small amounts of $\mathrm{Cu}^{2+}$ ions. In addition, vitamin $\mathrm{C}$ can inhibit various forms of T cell apoptosis. ${ }^{14}$ Supplementation of vitamin C caused a significant reduction in colonic epithelial cell proliferation in mice. ${ }^{15}$ Although vitamin $\mathrm{C}$ is present at signifi- cantly higher levels in gastric juice and gastric mucosal cells than in plasma or serum, ${ }^{2516}$ its effect on gastric epithelial cells remains unclear.

The effect of vitamin $\mathrm{C}$ on $H$ pylori growth and its pathogenicity has been reported by several groups. High dose vitamin $\mathrm{C}$ markedly inhibited $H$ pylori growth, colonisation, or even led to eradication of the organism; however, concentrations required in these studies were extremely high and often 10 times or greater than physiological levels in the stomach. ${ }^{17}{ }^{18}$ As an antioxidant, vitamin C has both antioxidant and pro-oxidant activities and large doses may promote kidney stones. ${ }^{19}$ Vitamin $\mathrm{C}$ is especially dangerous in the presence of high body iron stores, as iron promotes the pro-oxidant activity of vitamin $\mathrm{C}^{19}{ }^{19} \mathrm{~A}$ recent study showed that vitamin C intake greater than $500 \mathrm{mg} /$ day markedly increased its pro-oxidant activity and may actually induce host cell DNA damage, thereby increasing cancer risk. ${ }^{20}$

Hence understanding the role of physiological levels of vitamin $\mathrm{C}$ in the stomach is important in elucidating the protective properties of vitamin $\mathrm{C}$ against gastric carcinogenesis. In this study, we examined the in vitro effects of vitamin $\mathrm{C}$ at concentrations comparable with those found in gastric juice, on gastric cancer cell lines and H pylori pathogenicity to gastric epithelial cells.

\section{MATERIALS AND METHODS}

Cell culture

Gastric cancer cell lines, AGS and MKN 45, which were derived from gastric adenocarcinoma patients, were used. The cells were grown in RPMI 1640 medium containing 10\% fetal

Abbreviations: BrdU, bromodeoxyuridine; DHA, dehydroascobic acid; FITC, fluorescein isothiocyanate; NOC, N-nitroso compounds; PBS, phosphate buffered saline; $R B C s$, red blood cells; $R O M$, reactive oxygen metabolites. 
calf serum, penicillin $(100 \mathrm{U} / \mathrm{ml})$, streptomycin $(100 \mu \mathrm{g} / \mathrm{ml})$, and L-glutamine $(20 \mathrm{mM})$ and were maintained at $37^{\circ} \mathrm{C}$ in a humidified atmosphere of $5 \% \mathrm{CO}_{2}$ and $95 \%$ air. To assess the effects of vitamin $\mathrm{C}$ on gastric cancer cell growth and DNA synthesis, cells ( $1 \times 10^{4}$ cells/well in $200 \mu \mathrm{l}$ of culture medium) were plated in the inner 60 wells of a 96 well plate. The outer wells received $200 \mu \mathrm{l}$ of medium alone. A range of concentrations of vitamin C ( $\mathrm{L}$-ascorbic acid; Sigma-Aldrich Company Ltd, Dorset, UK) were added after 24 hours. Culture medium and vitamin $C$ were renewed after 48 hours of treatment. Cell viability, and protein and DNA synthesis were examined after 72 hours of treatment. Negative control cultures were cells that received medium alone.

\section{H pylori culture}

$H$ pylori strains NCTC 11637, SS1, and the SS1 isogenic pldA mutant (ND5- a phospholipase mutant) were used. Bacteria were grown on Columbia blood agar plates containing 5\% horse blood (Oxoid, UK) for 2-3 days under microaerobic conditions $\left(5 \% \mathrm{O}_{2}, 15 \% \mathrm{CO}_{2}, 80 \% \mathrm{~N}_{2}\right)$. To assess the effect of vitamin $\mathrm{C}$ on $\mathrm{H}$ pylori growth and adherence to gastric AGS cells, the bacterium $\left(1 \times 10^{7} \mathrm{cfu} / \mathrm{ml}\right)$ was grown in brain-heart infusion broth containing various amounts of $\mathrm{L}$-ascorbic acid at $37^{\circ} \mathrm{C}$ for up to 24 hours. The effect on survival after exposure to vitamin $\mathrm{C}$ was determined by viability count following serial 10-fold dilution on Dent's Columbia blood agar plates.

\section{Determination of cell protein and DNA synthesis}

Cell growth rates following vitamin $C$ treatment were assessed using a colorimetric protein assay with methylene blue staining. ${ }^{21}$ This technique is based on staining of basophilic cellular compounds (such as proteins, nucleic acid, etc) with methylene blue. Briefly, after incubation with various vitamin C concentrations, gastric AGS and MKN45 cells were washed with phosphate buffered saline (PBS, $\mathrm{pH}$ 7.4; the same $\mathrm{pH}$ was used in all subsequent experiments) and, subsequently, the cells were fixed with $10 \%(\mathrm{v} / \mathrm{v})$ formalin for 10 minutes at room temperature. After removal of formalin, cells were washed and stained with methylene blue $(1 \% \mathrm{w} / \mathrm{v}$ in borate buffer) for 10 minutes at room temperature. The excessive dye was removed by extensively washing with borate buffer. After drying, $200 \mu \mathrm{l}$ of $0.1 \mathrm{M} \mathrm{HCl}$ was added to each well and the plate was mixed for 15 minutes at room temperature using a plate shaker to facilitate dissolution of the stain. Optical density values were read in a microplate reader at $620 \mathrm{~nm}$. Results are expressed as percentage of untreated controls. Cell viability was determined by trypan blue exclusion assay. DNA synthesis in control and vitamin $C$ treated groups was assessed using a bromodeoxyuridine (BrdU) incorporation ELISA according to the manufacturer's instructions (Boehringer Mannheim, East Sussex, UK).

\section{Flow cytometric analysis for apoptosis and cell cycle phase distribution}

The effect of $H$ pylori on gastric cancer cell cycle phase distribution and apoptosis was assessed using flow cytometry according to a previously published method..$^{22}$ Briefly, a pool of detached and adherent cells was washed in PBS and the cells fixed in $70 \%$ ice cold $\left(4^{\circ} \mathrm{C}\right)$ ethanol overnight. The cell pellets were resuspended in a $1 \mathrm{ml}$ solution containing $200 \mu \mathrm{g} / \mathrm{ml}$ ribonuclease (Sigma, Dorset, UK) and $50 \mu \mathrm{g} / \mathrm{ml}$ propidium iodide (Sigma) for 60 minutes at $37^{\circ} \mathrm{C}$. Cell cycle analysis was performed on a FACScan flow cytometer (Becton Dickinson, Oxford, UK) equipped with a FACStation and CellQuest software (Becton Dickinson Immunocytometry Systems, Oxford, UK). Debris was eliminated from the analysis using a forward angle light scatter threshold. Cell doublets and clumps were gated out of the analysis using a dot plot display of area and width. A total of 10000 cells were analysed for each sample and the apoptotic cells were considered to constitute the sub-Gl cell population.

\section{$H$ pylori adherence assay}

Gastric AGS cells and H pylori SS I were used for assessment of $H$ pylori adherence according to the method described by Dunn and colleagues. ${ }^{23}$ Briefly, $H$ pylori SSI was preincubated in the presence of a range of concentrations of L-ascorbic acid for 30 or 120 minutes. Subsequently, AGS cells $\left(5 \times 10^{6}\right.$ cells $)$ and vitamin $\mathrm{C}$ pretreated $H$ pylori $\left(5 \times 10^{8}\right.$ organisms $)$ were incubated in PBS at $37^{\circ} \mathrm{C}$ for one hour with agitation (150 $\mathrm{rpm}$ ). Non-adherent bacteria were removed by centrifugation with $10 \mathrm{ml}$ of $15 \%$ sucrose solution. Cells were washed once with PBS and then incubated with a 1:5 dilution of polyclonal anti-H pylori antibody (SkyTek Laboratories, Logan, USA) on ice for 30 minutes. After washing with $15 \mathrm{ml}$ of PBS, cells were incubated for an additional 30 minutes on ice $\left(4^{\circ} \mathrm{C}\right)$ in a $1: 20$ dilution of fluorescein isothiocyanate (FITC) conjugated goat antirabbit IgG (Sigma-Aldrich Company Ltd). The cells were subsequently washed and resuspended in $1 \mathrm{ml}$ of $1 \%$ formaldehyde for flow cytometric analysis. The FACScan flow cytometer (Becton Dickinson, San Jose, USA) was used to measure bacteria adhering to AGS cells. By using a dot plot display of forward light scatter and side $\left(90^{\circ}\right)$ light scatter, the machine was gated to include single cells and to exclude cell debris and unbound bacteria. Fluorescence data were acquired in log model on a 256 channel by analysis of 10000 individual cells. The results were expressed as percentage of fluorescent cells calculated from fluorescence frequency distribution histograms. The threshold of cells without adherent bacteria was established for each experiment, the cells being stained with subsequent two step FITC conjugated $H$ pylori antibody staining, as described previously.

\section{Haemagglutination assay}

Red blood cells (RBCs) were obtained from defibrinated horse blood which was washed with PBS, resuspended in an equal volume of PBS, and kept at $4^{\circ} \mathrm{C}$. RBCs were prepared freshly every week. For the haemagglutination assay, H pylori SSI was pretreated with various concentrations of L-ascorbic acid in brain-heart infusion broth for up to 24 hours under microaerobic conditions. Subsequently, $50 \mu \mathrm{l}$ of 1\% RBC were mixed with $50 \mu \mathrm{l}$ of $H$ pylori $\left(5 \times 10^{8} \mathrm{cfu} / \mathrm{ml}\right)$ in a round bottomed 96 well microtitration plate. The plates were tapped to mix the interactants, left at room temperature for 30 minutes, and the results read after further incubation overnight at $4^{\circ} \mathrm{C}$ according to a previously described method. ${ }^{24}$

\section{Statistical analysis}

Differences were determined by the Student's $t$ test and $\mathrm{p}$ values $<0.05$ were considered significant in all analyses.

\section{RESULTS}

\section{Effect of vitamin C on gastric AGS and MKN45 cells}

Vitamin $C$ induced significant dose dependent inhibition of cell protein and DNA synthesis in gastric AGS and MKN45 cells, as measured by methylene blue colorimetric assay and BrdU incorporation ELISA (table 1). At concentrations similar to those found in the gastric juice of healthy subjects $(\geqslant 50$ $\mu \mathrm{M})$, vitamin C was markedly cytoxic to these cells and both protein and DNA synthesis were significantly inhibited. However, the effect was significantly reduced at levels similar to those in gastric juice of $H$ pylori infected patients $(<50 \mu \mathrm{M})$. Cell viability was also determined in AGS cells following 72 hours of exposure to vitamin $\mathrm{C}$ and a similar trend in the reduction in cell growth was observed, with 47.1 (15.9)\% inhibition at a vitamin C concentration of $100 \mu \mathrm{M}$ and 94.9 $(2.8) \%$ inhibition at $500 \mu \mathrm{M}$.

We further examined the relationship between cell concentration and vitamin $C$ induced AGS cell growth inhibition. The 
Table 1 Effect of vitamin $C$ on growth and proliferation of gastric AGS and MKN45 cells

\begin{tabular}{lllllll}
\hline & \multicolumn{2}{l}{ AGS } & & & MKN45 & \\
\cline { 2 - 3 } \cline { 5 - 6 } $\begin{array}{l}\text { Ascorbic acid } \\
(\mu \mathrm{M})\end{array}$ & Protein & Proliferation & & Protein & Proliferation \\
\hline 10 & $113(9)$ & $104(3)$ & & $102(5)$ & $101(4)$ \\
50 & $95(10)$ & $89(5)^{*}$ & & $97(8)$ & $90(2)$ \\
100 & $59(8)^{*}$ & $47(5)^{*}$ & & $78(3)^{*}$ & $83(2)^{*}$ \\
200 & $0^{*}$ & $0^{*}$ & & $38(1)^{*}$ & $16(3)^{*}$ \\
400 & $0^{*}$ & $0^{*}$ & & $4(3)^{*}$ & $0^{*}$ \\
\hline
\end{tabular}

Results are presented as percentage of untreated controls and each value (mean (SD)) represents an average of nine samples. ${ }^{*} \mathrm{p}<0.05$.
Table $2 \mathrm{pH}$ values in different ascorbic acid solutions $(n=3)$

\begin{tabular}{ll}
\hline & pH value \\
\hline O.5 M Ascorbic acid stock solution & $2.25(0.2)$ \\
Medium* alone (supplier's data) & $7.3(0.3)$ \\
Medium alone (measured) & $7.4(0.2)$ \\
Medium containing $500 \mu \mathrm{M}$ ascorbic acid & $7.4(0.3)$ \\
Medium containing $1000 \mu \mathrm{M}$ ascorbic acid & $7.3(0.2)$ \\
\hline
\end{tabular}

Values are (mean (SD)).

*RPMI 1640 (Sigma R0883)

effect of vitamin $\mathrm{C}$ on AGS cell viability was compared between cells treated in 24 well plates $\left(1 \times 10^{5}\right.$ cells $/ \mathrm{ml}$ seeding concentration) and those in 96 well plates $\left(1 \times 10^{4}\right.$ cells $/ \mathrm{ml}$ seeding concentration). After 72 hours of incubation, vitamin C induced only $32.5(2.4) \%$ inhibition in 24 well plates at a vitamin $\mathrm{C}$ concentration of $400 \mu \mathrm{M}$ but 94.3 (3.7)\% inhibition in 96 well plates at a vitamin C concentration of $200 \mu \mathrm{M}$ $(\mathrm{p}<0.0001)$. This finding suggests that gastric cell concentration is an important determinant in vitamin $\mathrm{C}$ induced in vitro cell damage.

As an acidic molecule, addition of vitamin $\mathrm{C}$ may influence the culture medium $\mathrm{pH}$ and therefore affect cell growth. ${ }^{25}$ The $\mathrm{pH}$ values of various vitamin $\mathrm{C}$ solutions involved in the study were determined using a $\mathrm{pH}$ meter (ABB Kent-Teylor Ltd, UK). There was no obvious alteration in $\mathrm{pH}$ values between original culture medium and those with various amounts of vitamin C (table 2 ).

\section{Effect of vitamin $\mathrm{C}$ on $\mathrm{H}$ pylori induced cell cycle phase distribution}

Following demonstration that vitamin $\mathrm{C}$ reduces growth and DNA synthesis in gastric cancer cell lines, we further examined its effect on $H$ pylori associated gastric cell cycle events. H pylori NCTC11637 were incubated with AGS cells in the absence or presence of L-ascorbic acid $(400 \mu \mathrm{M})$ for 48 hours. Treatment with vitamin $C$ showed a further enhancement of apoptosis induced by $H$ pylori $(\mathrm{p}<0.001)$ (fig 1 ). Analysis of surviving cells by flow cytometry showed an increased cell number in G0/Gl (gap 0/gap l phases) cell cycle phases $(p<0.0002)$ and decreased cell number in $\mathrm{G} 2 / \mathrm{M}$ (gap $2 /$ mitosis $)$ phases $(\mathrm{p}<0.01)$ compared with cells treated with $H$ pylori alone, indicating that vitamin C promoted G0/Gl cell cycle arrest in $\mathrm{H}$ pylori infected cells (fig 2).

\section{Effect of vitamin $\mathrm{C}$ on $\mathrm{H}$ pylori growth}

To examine the effect of vitamin $\mathrm{C}$ on $\mathrm{H}$ pylori growth at concentrations comparable with those found in gastric juice, we exposed $H$ pylori strains SSI and ND5 to a range of concentrations of L-ascorbic acid (0-400 $\mu \mathrm{M})$ for 24 hours. As shown in fig 3, the viability counts of both SS1 and ND5 were similar to

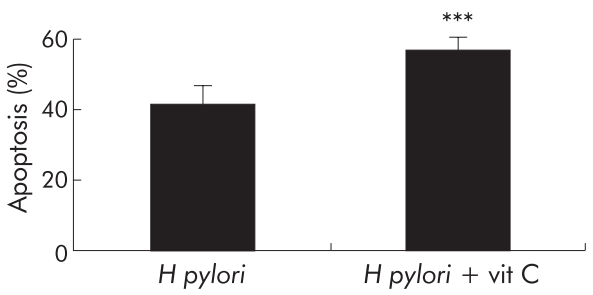

Figure 1 Effect of ascorbic acid (vit $\mathrm{C}$ ) on induction of Helicobacter pylori induced gastric AGS cell apoptosis. Gastric AGS cells were infected with $H$ pylori NCTC1 1637 in the presence or absence of $400 \mu \mathrm{M}$ ascorbic acid for 48 hours. Apoptosis was assessed by flow cytometry with propidium iodide staining and the results are the average of three experiments. ${ }^{* *} p<0.001$.

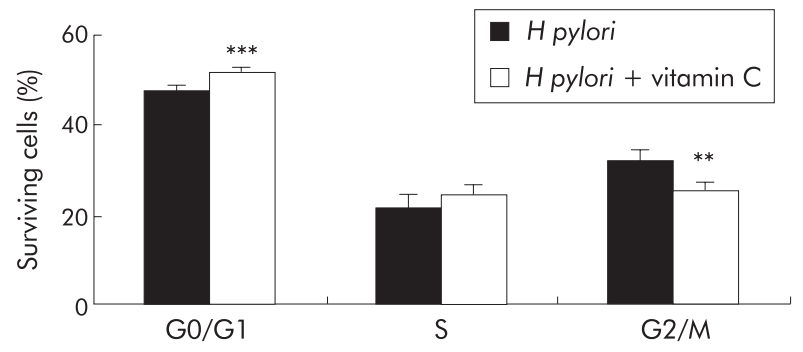

Figure 2 Effect of ascorbic acid (vitamin C) on Helicobacter pylori associated gastric AGS cell cycle phase distribution. Gastric AGS cells were infected with $\mathrm{H}$ pylori NCTC1 1637 in the presence or absence of $400 \mu \mathrm{M}$ ascorbic acid for 48 hours. Cell cycle phase distribution (gap 0/gap 1 phases (GO/G1), S phase, and gap $2 /$ mitosis (G2/M) phases) of surviving cells was analysed by flow cytometry with propidium iodide staining, and the results are the average of three experiments. ${ }^{* *} p<0.01 ;{ }^{* *} p<0.0002$.

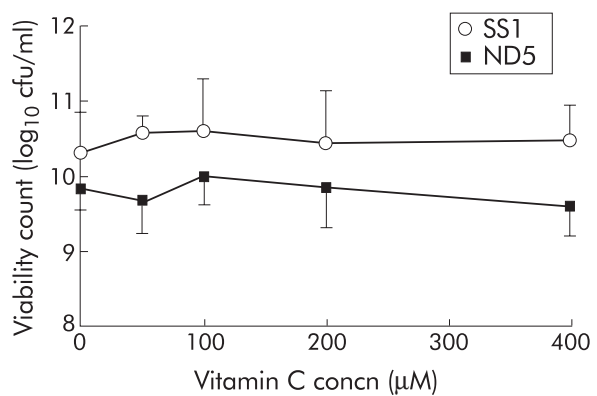

Figure 3 Effect of vitamin $\mathrm{C}$ on Helicobacter pylori growth. $H$ pylori strains SS1 and ND5 were exposed to various concentrations of vitamin $\mathrm{C}(0-400 \mu \mathrm{M})$ for 24 hours. Viability counts of $\mathrm{H}$ pylori were performed on Dent's Columbia blood agar plates. The results are an average of two experiments.

untreated controls following vitamin $\mathrm{C}$ treatment, suggesting that vitamin $\mathrm{C}$ at these concentrations had no effect on $\mathrm{H}$ pylori growth.

\section{Effect of vitamin $\mathrm{C}$ on $\mathrm{H}$ pylori adherence ability to gastric epithelial cells}

The ability to attach to the host cell is an essential step in pathogenesis for many bacteria. Previous studies have shown that vitamin $\mathrm{C}$ at high concentrations reduced the colonisation of $\mathrm{H}$ pylori to gastric mucosa. ${ }^{17}$ We assessed the effect of vitamin $\mathrm{C}$ on $\mathrm{H}$ pylori adherence to gastric AGS cells by pre-exposing $\mathrm{H}$ pylori to a range of concentrations of L-ascorbic acid $(0-400 \mu \mathrm{M})$ for 30 or 120 minutes. Flow cytometric analysis showed that there was no significant difference in the adherence to gastric AGS cells for either 30 or 120 minutes of vitamin $C$ pretreated $H$ pylori compared with untreated $H$ pylori (table 3 ), suggesting that vitamin $\mathrm{C}$ had no effect on the ability of $H$ pylori to adhere to gastric AGS cells. 
Table 3 Effect of vitamin $C$ on the ability of Helicobacter pylori to adhere to gastric AGS cells

Adhesion rate (\% control (SD))

\begin{tabular}{lrr} 
Vitamin C & \multicolumn{1}{c}{$30 \mathrm{~min}$} & \multicolumn{1}{c}{$120 \mathrm{~min}$} \\
\hline $100 \mu \mathrm{M}$ & $102.4(3.2)$ & $99.8(6.7)$ \\
$200 \mu \mathrm{M}$ & $96.1(6.7)$ & $102.8(4.6)$ \\
$400 \mu \mathrm{M}$ & $93.1(15.4)$ & $103.5(8.9)$ \\
\hline
\end{tabular}

* Results are the average of five experiments.

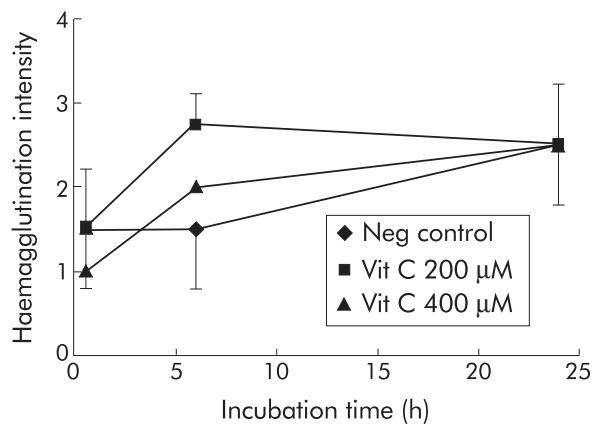

Figure 4 Effect of vitamin $\mathrm{C}$ on Helicobacter pylori haemagglutination activity. Horse red blood cells $(1 \%)$ and ascorbic acid pretreated SS $1\left(5 \times 10^{8} \mathrm{cfu} / \mathrm{ml}\right)$ were incubated in an equal volume (50 $\mu$ leach) in a round bottomed 96 well microtitration plate. The plates were left at room temperature for 30 minutes and the results were read after further incubation overnight at $4^{\circ} \mathrm{C}$.

\section{Effect of vitamin $\mathrm{C}$ on $\boldsymbol{H}$ pylori haemagglutination activity}

Bacterial attachment to host cells is mediated by adhesins or ligands which can be assessed by haemagglutination assay. ${ }^{24}$ To further examine the possible effect of vitamin $\mathrm{C}$ on $\mathrm{H}$ pylori pathogenicity and to confirm our results regarding the effect of vitamin $\mathrm{C}$ on $\mathrm{H}$ pylori adherence, $\mathrm{H}$ pylori haemagglutinating activity following addition of L-ascorbic acid was determined. As shown in fig 4, regardless of the dose of vitamin $\mathrm{C}$ or duration of pretreatment, $H$ pylori induced haemagglutination in all wells. This suggests that vitamin $\mathrm{C}$ at concentrations of 0-400 $\mu \mathrm{M}$ had no obvious effect on the haemagglutination activity of $H$ pylori.

\section{DISCUSSION}

Vitamin C is thought to be an important local protective factor against gastric carcinogenesis. H pylori infection induces marked infiltration of inflammatory cells within the gastric mucosa; these inflammatory cells such as neutrophils and monocytes synthesise and release copious amounts of toxic $\mathrm{ROMs}^{26}$ which may be neutralised by vitamin $\mathrm{C}$ and other antioxidants in the stomach. Gastric epithelial cells actively secrete ascorbic acid, the reduced form of vitamin C, into gastric lumen, where there is a significantly higher concentration than that in plasma in healthy subjects. ${ }^{27}{ }^{28}$ There is variation in gastric juice concentrations of vitamin C (ascorbic acid alone or plus DHA) in healthy subjects according to the methods and subjects involved in the studies. Although low levels have been reported, ${ }^{29}$ most studies in the fasting stomach have detected ascorbic acid concentrations in the range 50 to 400 $\mu \mathrm{M}$. However, gastric juice vitamin $\mathrm{C}$ is significantly reduced or even absent in H pylori infection. ${ }^{51627283031}$ This reduction in gastric juice vitamin $\mathrm{C}$ concentration is restored to normal after $H$ pylori eradication, indicating that the defect in vitamin $\mathrm{C}$ transport and $H$ pylori induced gastric cell damage is reversible. ${ }^{3}$ For the present study, we set $0-400 \mu \mathrm{M}$ ascorbic acid as the physiological range which would include healthy subjects and those with $H$ pylori infection.

It has been proposed that vitamin $\mathrm{C}$ may have a major role in preventing gastric cancer by inhibiting the formation of NOCs and neutralising the toxicity of ROMs in the stomach. However, previous studies have suggested that vitamin $\mathrm{C}$ may also directly interfere with the synthesis of host cell DNA, RNA, and protein, and thereby inhibit cell proliferation and induce cell death in some cell systems. ${ }^{32}{ }^{33}$ The relationship between gastric epithelial cell growth and vitamin C, especially at concentrations of vitamin C comparable with those present in gastric juice, remains unknown. To examine the effect of vitamin $\mathrm{C}$ on gastric cancer cells, three methods were used to assess cell growth and proliferation following vitamin $\mathrm{C}$ treatment. We observed an obvious dose dependent inhibition of growth for both AGS and MKN45 cells. As cell viability decreased, protein and DNA synthesis were inhibited. These data indicate that vitamin $\mathrm{C}$ is capable of inducing gastric cancer cell growth inhibition, which may be related to the effects on cell protein and DNA synthesis. Whether the inhibition is specific for gastric cancer cells or also occurs in normal gastric epithelial cells is not known. However, current evidence suggests that vitamin $C$ metabolism in neoplastic and non-neoplastic cells is remarkably different. The ascorbic acid secretion mechanisms may be impaired in tumour cells as loss of intracellular ascorbic acid from some gastric cancer cells, including AGS cells, is slower than that seen in normal gastric epithelial cells. ${ }^{34}$ There is also evidence that vitamin C concentrations are higher in neoplasms compared with the adjacent normal tissue. ${ }^{35} 36$

Because vitamin $\mathrm{C}$ is an acidic molecule and might alter the $\mathrm{pH}$ of culture medium and inhibit cell growth, we examined this possibility and confirmed that $\mathrm{pH}$ was unchanged following addition of vitamin $\mathrm{C}$ (table 2 ). Furthermore, as reported in other cell systems, we found that the gastric cell density used in these experiments was important in determining the degree of cell growth inhibition. ${ }^{8}$ We compared the cell viability of gastric AGS cells following vitamin C exposure in 96 well and 24 well plates and found that high cell concentrations exhibited less cell growth inhibition than low concentrations, suggesting that cell concentration is an important determinant in vitamin $\mathrm{C}$ induced gastric cancer cell growth inhibition.

The protective role of gastric juice vitamin $\mathrm{C}$ against gastric carcinogenesis could also be related to a direct effect on $H$ pylori. Infection with the bacteria causes significant reduction of gastric juice vitamin $C$ concentration through the development of chronic gastritis and/or $H$ pylori oxidase activity. ${ }^{37}$ On the other hand, vitamin $C$ may also be capable of inhibiting $H$ pylori growth. Jarosz et al treated $H$ pylori positive dyspeptic patients with vitamin C $5 \mathrm{~g}$ daily for four weeks. They showed that $H$ pylori infection was eradicated in eight of 27 patients $(30 \%)$ and gastric juice vitamin C level was significantly higher in patients who underwent successful clearance of the bacteria than in those with persistent $H$ pylori infection. ${ }^{18} \mathrm{~A}$ recent study in Mongolian gerbils also suggests that supplementation with vitamin C $10 \mathrm{mg}$ daily (equivalent to $12 \mathrm{~g}$ daily in humans), reduced colonisation of $H$ pylori. ${ }^{17}$ Thus a pharmacological supplement of vitamin $C$ may be of value in the control of $H$ pylori infection whereas physiological levels of vitamin $\mathrm{C}$ in gastric juice may be important in the prevention of $H$ pylori infection and gastric carcinogenesis. We examined therefore the effect of vitamin $\mathrm{C}$ at physiological levels on $H$ pylori growth and its pathogenicity. It has been suggested that vitamin $\mathrm{C}$ is extremely unstable in the presence of $H$ pylori and can be degraded within 30 minutes. ${ }^{17} 3738$ Hence we examined the effect of vitamin $\mathrm{C}$ at 30 minutes and 24 hours after treatment. The effect of vitamin $\mathrm{C}$ on $H$ pylori growth was tested at different concentrations ranging from 0 to $400 \mu \mathrm{M}$ and we found that vitamin $\mathrm{C}$, in this concentration range, showed no effect on $H$ pylori growth. A recent study using a regular MIC 
determination by the agar dilution method showed similar results. ${ }^{17}$ Furthermore, there was also no effect on the ability of $H$ pylori to adhere to gastric AGS cells or on haemagglutinating activity of the bacteria. Data from the present study therefore suggest that vitamin $C$ at levels comparable with those found in gastric juice have no effect on $H$ pylori growth and the ability to adhere to gastric epithelial cells.

We also observed that vitamin $\mathrm{C}$ enhanced induction of apoptosis and increased the percentage of cells in the G0/Gl phases of the cell cycle in $H$ pylori infected gastric AGS cells. The underlying mechanisms remain unclear. However, it is unlikely to be related to antioxidant activity as vitamin $\mathrm{C}$ is rapidly broken down in the presence of $H$ pylori. We assessed the effect after 48 hours of exposure to vitamin $\mathrm{C}$ and $H$ pylori which makes it most likely that these observation were due to vitamin $\mathrm{C}$ oxidative products rather than native vitamin $\mathrm{C}$. Clearly, further studies are needed to examine the possible mechanisms by which vitamin $C$ has these effects on gastric cancer cells.

In conclusion, vitamin $\mathrm{C}$ may inhibit the growth of gastric cancer cells at concentrations comparable with those found in normal gastric juice but we found no effect on $H$ pylori growth or the ability to adhere to gastric epithelial cells. However, the inhibitory effect on gastric cancer cells may be lost as vitamin C concentrations decrease during $H$ pylori infection.

\section{Authors' affiliations}

Z-W Zhang, M Abdullahi, M J G Farthing, Digestive Diseases Research Centre, St Bartholomew's and the Royal London School of Medicine and Dentistry, London, UK

\section{REFERENCES}

1 Williams MP, Pounder RE. Helicobacter pylori: from the benign to the malignant. Am J Gastroenterol 1999;94:S11-16.

2 Reed PI. Vitamin C, Helicobacter pylori infection and gastric carcinogenesis. Int J Vitam Nutr Res 1999;69:220-7.

3 Correa P, Malcom G, Schmidt B, et al. Review article: Antioxidant micronutrients and gastric cancer. Aliment Pharmacol Ther 1998;12(suppl 1):73-82.

4 Zhang ZW Farthing MU. Helicobacter pylori and gastric malignancy: Importance of oxidants, antioxidants and other co-factors. In: Hunt RH, Tytgat GNJ, eds. Helicobacter pylori: Basic mechanisms to clinical cure 2000. London: Kluwer Academic Publishers, 2000:513-24.

5 Zhang ZW, Patchett SE, Perrett $D$, et al. The relation between gastric vitamin $\mathrm{C}$ concentrations, mucosal histology, and CagA seropositivity in the human stomach. Gut 1998:43:322-6.

6 Phull PS, Price AB, Thorniley MS, et al. Plasma free radical activity and antioxidant vitamin levels in dyspeptic patients: correlation with smoking and Helicobacter pylori infection. Eur J Gastroenterol Hepatol 1998; 10:573-8

7 Bates CJ. Bioavailability of vitamin C. Eur J Clin Nutr 1997;51/suppl 1):S28-33

8 Brigelius-Flohe R, Flohe L. Ascorbic acid, cell proliferation, and cell differentiation in culture. Subcell Biochem 1996;25:83-107.

9 Sakagami $\mathbf{H}$, Satoh K. Modulating factors of radical intensity and cytotoxic activity of ascorbate. Anticancer Res 1997; 17:3513-20.

10 Bram S, Froussard P, Guichard M, et al. Vitamin C preferential toxicity for malignant melanoma cells. Nature 1980;284:629-31.

11 Satoh K, Ida Y, Hosaka M, et al. Induction of apoptosis by cooperative action of vitamins $C$ and $E$. Anticancer Res 1998;18:4371-5.
12 Denk PO, Knorr M. In vitro effect of ascorbic acid on the proliferation of bovine scleral and Tenon's capsule fibroblasts. Eur J Ophthalmol 1998:8:37-41

13 Peterkofsky B, Prather W. Cytotoxicity of ascorbate and other reducing agents towards cultured fibroblasts as a result of hydrogen peroxide formation. J Cell Physiol 1977:90:61-70.

14 Campbell JD, Cole M, Bunditrutavorn B, et al. Ascorbic acid is a potent inhibitor of various forms of T cell apoptosis. Cell Immunol 1999; 194: 1-5

15 Deschner EE, Alcock N, Okamura T, et al. Tissue concentrations and proliferative effects of massive doses of ascorbic acid in the mouse. Nutr Cancer 1983:4:241-6.

16 Waring AJ, Drake IM, Schorah CJ, et al. Ascorbic acid and total vitamin $\mathrm{C}$ concentrations in plasma, gastric juice, and gastrointestinal mucosa: effects of gastritis and oral supplementation. Gut 1996;38:171-6.

17 Zhang HM, Wakisaka N, Maeda O, et al. Vitamin C inhibits the growth of a bacterial risk factor for gastric carcinoma: Helicobacter pylori. Cancer 1997;80:1897-903.

18 Jarosz M, Dzieniszewski J, Dabrowska-Ufniarz E, et al. Effects of high dose vitamin $C$ treatment on Helicobacter pylori infection and total vitamin $C$ concentration in gastric juice. Eur J Cancer Prev 1998;7:449-54

19 Herbert V. The antioxidant supplement myth. Am J Clin Nutr 1994;60:157-8.

20 Podmore ID, Griffiths HR, Herbert KE, et al. Vitamin C exhibits pro-oxidant properties. Nature 1998:392:559

21 Pelletier B, Dhainaut F, Pauly A, et al. Evaluation of growth rate in adhering cell cultures using a simple colorimetric method. J Biochem Biophys Methods 1988;16:63-73.

22 Ormerod MG. Analysis of DNA: general methods. In: Ormeron MG, ed. Flow cytometry: a practical approach, vol 1, 2nd edn. New York: Oxford University Press Inc, 1994:119-36.

23 Dunn BE, Altmann M, Campbell GP. Adherence of Helicobacter pylori to gastric carcinoma cells: analysis by flow cytometry. Rev Infect Dis $1991 ; 13$ (suppl 8):S657-64.

24 Robinson J, Goodwin CS, Cooper M, et al. Soluble and cell-associated haemagglutinins of Helicobacter (Campylobacter) pylori. J Med Microbiol 1990;33:277-84.

25 Shao JC, Yorioka N, Nishida Y, et al. Effect of $\mathrm{pH}$ and glucose on cultured human peritoneal mesothelial cells. Scand J Urol Nephrol $1999 ; 33: 248-56$

26 Conner EM, Grisham MB. Inflammation, free radicals, and antioxidants. Nutrition 1996:12:274-7.

27 Schorah CJ. The transport of vitamin $\mathrm{C}$ and effects of disease. Proc Nutr Soc 1992:51:189-98

28 Muto N, Ohta T, Suzuki T, et al. Evidence for the involvement of a muscarinic receptor in ascorbic acid secretion in the rat stomach. Biochem Pharmacol 1997;53:553-9.

29 Rood JC, Ruiz B, Fontham ETH, et al. Helicobacter pylori associated gastritis and the ascorbic acid concentration in gastric juice. Nutr Cancer 1994; 22:65-72.

30 Banerjee S, Hawksby C, Miller S, et al. Effect of Helicobacter pylori and its eradication on gastric juice ascorbic acid. Gut 1994;35:317-22.

31 Sobala GM, Schorah CJ, Sanderson M, et al. Ascorbic acid in the human stomach. Gastroenterology 1989;97:357-63.

32 Lupulescu A. Vitamin C inhibits DNA, RNA and protein synthesis in epithelial neoplastic cells. Int J Vitam Nutr Res 1991;61:125-9.

33 Lupulescu A. Ultrastructure and cell surface studies of cancer cells following vitamin C administration. Exp Toxicol Pathol 1992;44:3-9

34 Waring AJ, Schorah CJ. Transport of ascorbic acid in gastric epithelial cells in vitro. Clin Chim Acta 1998;275:137-49.

35 Langemann $\mathbf{H}$, Torhorst J, Kabiersch A, et al. Quantitative determination of water- and lipid-soluble antioxidants in neoplastic and non-neoplastic human breast tissue. Int J Cancer 1989;43:1 169-73.

36 Agus DB, Vera JC, Golde DW. Stromal cell oxidation: a mechanism by which tumors obtain vitamin C. Cancer Res 1999:59:4555-8.

37 Ødum L, Andersen LP. Investigation of Helicobacter pylori ascorbic acid oxidating activity. FEMS Immunol Med Microbiol 1995;10:289-94.

38 Johnson AW, Aleksandrowicz J, Tompkins DS, et al. The effect of Campylobacter pylori on ascorbic acid and urea metabolism in vitro. In: Megraud F, Lamouliatte H, ed. Gastroduodenal pathology and Campylobacter pylori, vol 1. Amsterdam: Elsevier Science Publishers, 1989:405-7. 